\title{
Interspace: vzdálenost jako kompoziční strategie
}

\section{Interspace: Distance as a Composition Strategy}

Slavomír Hořínka / slavomir@horinka.cz

Department of Composition, Music and Dance Faculty, Academy of Performing Arts, Prague, CZ.

\begin{abstract}
Not many, but some scholars deal with the issue of space in music. Most of them reduce this topic to dislocation of musicians out from the stage or around the public. Does it means that the frontal location of performers on the stage prevent spatial strategies of composer? In my paper I am focusing on spatio-temporal compositional strategies dealing with perception of distance in musical composition placing the sound sources in front of the listener: physical (outer) and structural (inner). Situations includes foreground / background (juxtaposition), depth (perspective) and zooming the source (focusing). Examples are taken from the works of G. Mahler, S. Reich, L. Dallapiccola, M. Górecki, T. Takemitsu, E. Varése, S. Sciarrino, J. Harvey, G. Grisey and O. Messiaen.
\end{abstract}

\section{Keywords}

interspace, spatial music, distance, space, juxtaposition, depth, perspective, zooming, focusing, Gustav Mahler, Steve Reich, Luigi Dallapiccola, Henryk Górecki, Toru Takemitsu, Edgard Varèse, Salvatore Sciarrino, Jonathan Harvey, Gérard Grisey, Olivier Messiaen 
Když uvažujeme o naší prostorové zvukové zkušenosti a jejím vztahu ke kompozičním strategiím skladatele, nejspíse nás napadne jako jedna z prvních možností situace, kdy nástroje (zvukové zdroje) jsou umístěny okolo publika. Prostorovými aspekty instrumentální hudby se zabývá poměrně málo dostupných prací a není s podivem, že drtivá většina $\mathrm{z}$ nich toto téma redukuje právě na kompozice $\mathrm{s}$ nástroji dislokovanými mimo koncertní pódium. ${ }^{1}$ To je ovšem jen uzounká výseč komplexní problematiky vztahu hudby a prostoru. ${ }^{2} \mathrm{Jsem}$ toho názoru, že jednotlivé aspekty prostorové poslechové zkušenosti jsou v př́mém vztahu s hudebními strukturami od gregoriánského chorálu po současnost. Chtěl bych tento text zacílit směrem, který by se mohl zdát na první pohled tím nejméně zajímavým, avšak opak je pravdou. A to na využití parametru vzdálenosti jakožto kompoziční strategie při frontálním umístění zvukových zdrojů - nástrojů na pódiu před posluchačem.

\section{Vztah popředí a pozadí (juxtapozice)}

Jedním ze základních archetypů vnímání, a to v případě jakéhokoli umístění zvukových zdrojů, je hierarchizace několika současně znějících zvukových událostí. ${ }^{3}$ Zaměření sluchu na to, co je pro nás podstatné a odsunutí toho méně důležitého do pozadí je vlastní nejen nám, ale i řadě dalších tvorů a je jednou z podmínek schopnosti komunikace. Zcela jistě není náhodné, že hudba i řeč zapojují neuronovou sít celého mozku. Mnohé z oblastí dokonce sdílejí, avšak každá dominuje jiné hemisféře. ${ }^{4}$ Popředí a pozadí našeho vnímání nemusí být nutně závislé na vzdálenosti zvukových zdrojů od nás, jako spíše na jejich hlasitosti a subjektivní výraznosti či důležitosti. Jinými slovy jakým způsobem upoutají naši pozornost. Svou pozornost však můžeme také vědomě zaměřit na konkrétní zdroj zvuku, zvláště tehdy, když se na něj můžeme soustředit také zrakem. ${ }^{5}$

Zvukové události pozadí většinou splývají do kontinua, zatímco události popředí člení čas povětšinou hierarchicky. Naše vnímání má však tendenci interpretovat je právě opačně. V popředí hledáme souvislosti a kontinuitu a pozadí si všímáme často nahodile, nárazově a vnímáme jej tudíž diskontinuálně. Dynamicky výrazné zvukové události s nehierarchickým průběhem v čase (napřs. dlouho znějící siréna nebo zatloukání dřevěných pilotů), máme tendenci po určité době (i přes jejich hlasitost a výraznost) vytlačit do pozadí.

1 V tomto smyslu je podnětná práce Martha Brech, Ralph Paland (Hg. / Eds.). Kompositionen für hörbaren Raum / Compositions for Audible Space, v českém kontextu napr. T. Pálka Prostor a tektonika v hudebni kompozici.

2 Tím nechci říci, že tento přístup není nosný. Sám se jím ve své tvưrčí i výzkumné činnosti aktivně zabývám.

3 Srov. synecdoche effect. AUGOYARD, Jean-François - TORGUE, Henry. Sonic Experience: a Guide to Everyday Sounds. s. 123-129.

4 FALK, D. Hominid Brain Evolution and the Origins of Music. In WALLIN, Nils Lennart - MERKER, Björn - BROWN, Steven (eds.). The Origins of Music. MIT Press, 1999.

5 Srov. tzv. coctail party effect. CHERRY, Colin E. Some Experiments on the Recognition of Speech, with One and with Two Ears. 
Typickým příkladem vztahu práce s popředím a pozadím je vztah melodie a doprovodu v klasicko-romantické hudbě. Nahlížíme-li na tuto relaci z pozice prostorového vnímání, není absence harmonicko-melodické složky novější hudby zas až tak zásadní změnou. Ano, tento konkrétní způsob práce s popředím a pozadím mnohdy není př́ítomen, ale existují i jiné prrístupy, jak s hierarchizací několika současně znějících událostí nakládat. V tomto smyslu je začátek Mahlerovy 6. symfonie (1903-1904, rev. 1906) téměř prorocký. Objevuje se v něm instrumentačně specificky pojatý spoj akordů A dur - a moll, který hrají zároveň trompety ${ }^{6}$ a hoboje, doprovázené tympány a vírem trianglu. Trompety a hoboje mají důmyslnou inverzní dynamiku, čímž dochází $\mathrm{k}$ jedinečné barvené vypointovanosti: v akordu A dur jsou v popředí trompety, v a moll jsou to naopak hoboje, zatímco celková dynamika postupně klesá. ${ }^{7}$

Podobným způsobem nechává Steve Reich na začátku Music for 18 Musicians vystupovat $\mathrm{z}$ homogenního, pravidelně tepajícího proudu do popředí jednotlivé nástroje či skupiny a opět je noří zpět. Plynulost gest je podpořena pravidelným pulsem všech zúčastněných nástrojů. Puls na jednu stranu díky své nespojitosti minimalizuje př́ípadné nežádoucí „schody“ při hře s juxtapozicí nástrojových barev, na druhou stranu nehierarchickým členěním času vytváří pocit kontinua. Výsledný dojem je podobný situaci, kdy se nalézáme v prostředí komplexní zvukové krajiny a vědomě zaměřujeme svou pozornost na jednotlivé zvukové zdroje, které se v ní nacházejí.

Na rozdíl od Reicha Luigi Dallapiccola ve skladbě Piccola musica notturna (1954, verze pro orch.) dosahuje mezi popředím a pozadím záměrně výrazného oddělení. Autor pracuje s interakcí dvou odlišně pojatých pásem. První má spíše komorní sazbu, jemný zvuk. Do něj ostrými vpády vstupuje pásmo druhé, které je založeno převážně vertikálně, charakterizuje jej výrazný perkusní atak. Dojem z poslechu této skladby bych přirovnal ke klidné chvíli před usnutím, která je narušována neočekávanými zvukovými událostmi, jež nás z usínání vytrhávají. ${ }^{8}$ Tektonika skladby připomíná tzv. cut-out effect, tedy vytlačení vnímaného zvukového popředí z našeho vnímání jiným výraznějším zvukem. ${ }^{9}$

Musíme si uvědomit, že z hlediska sluchového rozlišování a lokalizace zvukových zdrojů je veliký rozdíl, jestliže jsou umístěny daleko od sebe (okolo nás) nebo blízko sebe (před námi). Prostorové oddělení zvukových zdrojů má z hlediska čitelnosti hudební struktury podobný efekt jako např. umístění současně znějících struktur do rozdílných rejstř́ků v tónovém prostoru. Naopak při umístění zvukových zdrojů na pódiu (frontální poslech) musí mít ta vrstva hudební struktury, která má být v popředí pozornosti okolo sebe dostatečný akustický prostor. $\mathrm{V}$ opačném případě má tendenci být maskována. ${ }^{10} \mathrm{To}$ je typický problém četných instrumentálních koncertů, ${ }^{11}$ ba ještě zásadnější kámen úrazu

6 Hovořím li o trompetách mám (zjednodušeně řečeno) na mysli nástroj o dvojnásobné délce vzduchového sloupce oproti moderní trubce. Srov. Jan RYCHLÍK a kol. Moderní instrumentace: vy̌šš orchestračni technika jednotlivých hudebnich nástrojü. Praha: Panton, 1968, s. 148n.

7 Podobné, ale mnohem komplexnější gesto můžeme najít mezi takty 14-20 v Ligetiho Atmosphéres (1961).

8 HOŘíNKA, Slavomír. Barva zvuku a hierarchie v tektonice, s. 35n.

9 AUGOYARD, Jean-François - TORGUE, Henry. Sonic Experience: a Guide to Everyday Sounds. s. 29-37.

10 Viz BURGHAUSER, Jarmil - ŠPELDA, Antonín. Akustické základy orchestrace. Praha: Panton, 1967.

11 Samozřejmě může být autorovým záměrem přesný opak - nechat sólový nástroj splynout s okolím. 
mnoha vokálních děl s orchestrem.

Maskování zvukových zdrojů přebujelým pozadím, které tyto zdroje odsune mimo naši pozornost, je realita zvukové krajiny současnosti. Zvýšená hladina zvuku provází lidská sídla odnepaměti a je zřejmé, že si lidé uvědomovali negativní stránku tohoto faktu. ${ }^{12}$ Např. již ve starověkém Římě platil zákaz noční jízdy vozů, protože dělaly hluk na dlážděných ulicích. ${ }^{13}$ Jako rušivý nemusíme vnímat zdaleka jen zvuk neperiodické povahy. Vzpomeňme na karikaturu Williama Hogartha The Enraged Musician (1741) na níž vidíme rozličné zdroje zvuků, které nedovolují houslistovi cvičit (viz obr. 1). Goethe nesnášel štěkání psů, Shopenhauer si zase stěžoval na počínání vozků šlehajících bičem. ${ }^{14} \mathrm{~V}$ dů-

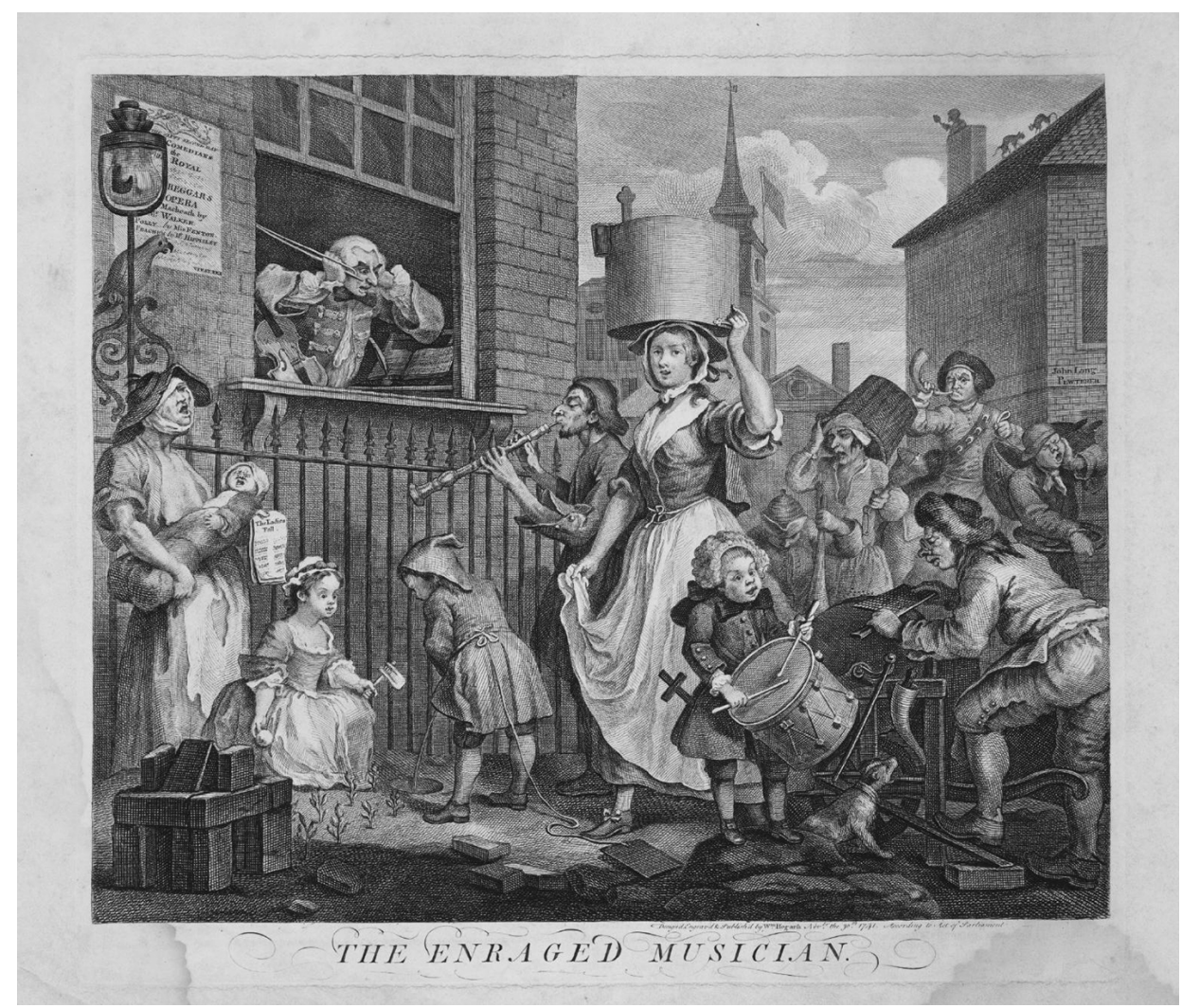

Obr. 1 William Hogarth: The Enraged Musician (1741). Zdroj: [online]. [cit. 2017-11-05]. Dostupné z: http://www.tate.org.uk/art/images/work/T/T01/T01800_10.jpg.

12 "An inability to stay quiet is one of the most conspicuous failings of mankind“ (Walter Bagehot)

13 GOINES, Lisa - HAGLER, Louis. Noise Pollution: A Modern Plague. South Med J., 2007, Mar., 100, 3, s. 287-94.

14 THOMPSON, Emily Ann. The Soundscape of Modernity: Architectural Acoustics and the Culture of Listening in America, 1900-1933. Cambridge, Mass [u.a.]: MIT Press, 2008, s. 116. 
sledku industrializace, zvláště pak v posledních dekádách s nástupem automobilismu a letecké dopravy, došlo k obrovskému nárůstu akustického znečištění zvukové krajiny naší planety. ${ }^{15}$ „Žijeme uprostřed hluku, jimž je naše existence čím dál více ovládána. Poněvadž musime v tomto hluku žit, vbrzku všichni ohluchneme. "16

Těžko bychom ve městech hledali místo, kde bychom nebyli vystaveni zvuku dopravy všeho druhu. Intenzitu tohoto zvuku si uvědomíme až na místech, kde bychom očekávali ticho (např. v parku), ale slyšíme konstantní hukot v dálce. ${ }^{17}$ Došlo k tomu, že jsme obrovskou škálu jemnějších, zvláště přírodních zvuků, které byly v dřívějších dobách samozřejmou součástí každodenního života, odsunuli do pozadí našeho vnímání. Někdy mám pocit, že se naše zvuková krajina stala dvojrozměrnou a my obýváme jen její zvukově uniformní popředí, ${ }^{18}$ které si sami vytváříme, aniž bychom byli schopni si uvědomovat její přirozenou hloubku. ${ }^{19}$ Obávám se, že nenávratně ztrácíme dříve tak běžné příležitosti k rozvíjení naší schopnosti rozlišení jemných zvukových podnětů. Bylo by naivní myslet si, že takováto proměna zvukového prostředí nebude mít vliv na tvůrčí proces skladatele. ${ }^{20}$

Domnívám se, že tyto skutečnosti mohou být jedním z důvodů, proč se dnes někteří skladatelé zaměřují na ty nejtišší zvuky, které jsou za normálních okolností pod naší rozlišovací schopností. ${ }^{21} \mathrm{Na}$ druhou stranu můžeme pozorovat v hudbě dnešní doby nárůst užití prodlevy a statičnosti hudebního vývoje. A to nemám na mysli jen tzv. drone music. ${ }^{22}$ Je zřejmé, že způsob poslechu je vysoce individuální a souvisí také se zvukovými vlastnostmi mateřského jazyka, kulturně-náboženským a geografickým vlivem. Hezky to vystihl Toru Takemitsu:

„The bells of Westminster Abbey speak in terms of first person singular: they have an individual motive with a distinctive statement. The Japanese temple gong, however, speaks without personal identification: its sound seems to melt into the world beyond persons, static and sensual.“23

15 Viz hi-fi \& lo-fi soundscape. TROJAN, J. Akustická ekologie a soundscape v kontextu multimédii. Disertační práce. HAMU, 2012, s. 28-30.

16 HONEGGER, Arthur. Jsem skladatel, 1. vyd. Bratislava Praha: Supraphon, 1967, s. 22.

17 Ich möchte „singen, wie der Vogel singt, der in den Zweigen wohnet" (Uhland), indes wohnen wir auf Zweigen eines kaputten Waldes. LACHENMANN, Helmut. Musik als existentielle Erfahrung, s. 104.

18 "It is a simplification, but one which is suggestive: hi-fi soundscapes are varied and uniquely local; lo-fi soundscapes are uniform and about the same every-where." TRUAX, B. Soundscape Composition as Global Music: Electroacoustic music as soundscape, s. 104.

$19, \ldots[$... [ the lo-fi soundscape seems to create a common habit of non-listening “ Ibid.

20 Vzpomeňme na počáteční fascinaci touto zvukovou proměnou u futuristů, počátky širší popularity jazzu, Varéseho americké skladby, či dnešní noisovou scénu. Srov. sharawadji effect. AUGOYARD, Jean-François TORGUE, Henry. Sonic Experience: a Guide to Everyday Sounds, s. 117-123.

21 Viz následující část o změně měřítka poslechu.

22 Opakovaně si tohoto faktu povšimli starší kolegové při seminářích katedry skladby na pražské HAMU. Tuto tendenci vnímám i ve vlastní tvorbě.

23 TAKEMITSU, Toru. Confronting Silence. Berkeley, California, 1995. s. 10-11. 


\section{Hloubka frontálního poslechu (perspektiva)}

Představme si, že se nalézáme u jezera a na protějším břehu stojí člověk, se kterým se snažíme vést rozhovor. Klidná vodní hladina funguje přirozeně jako zvukový reflektor, takže rozumíme každému slovu. Rozdíl mezi námi a odpověd'mi našeho protějšku bude pro nás ale z hlediska vjemu vzdálenosti naprosto zásadní, nebot je to rozdíl mezi nejbližším možným ${ }^{24}$ a vzdáleným. Zvukový zdroj, který je blízko, bude vždy silnější, jasnější a s menším dozvukem oproti stejnému zdroji, avšak vzdálenému. Ten bude logicky slabší, barevně pozměněný (ochuzený zvláště o vyšší složky harmonického spektra) a s adekvátně delším dozvukem. Obraz rozhovoru mezi dvěma subjekty, potažmo princip otázky a odpovědi je jedním z archetypů, který můžeme v hudbě vysledovat odnepaměti. ${ }^{25}$

Zajímavou paralelu představuje provozovací praxe violového consortu $\mathrm{v}$ Anglii 16. a 17. století. Typické rozmístění hráčů je zachyceno na obraze Alegorie sluchu (1618) od Jana Brueghela staršího (viz obr. 2) ${ }^{26}$. Hráči, sedíce obyčejně okolo stolu, byli zároveň

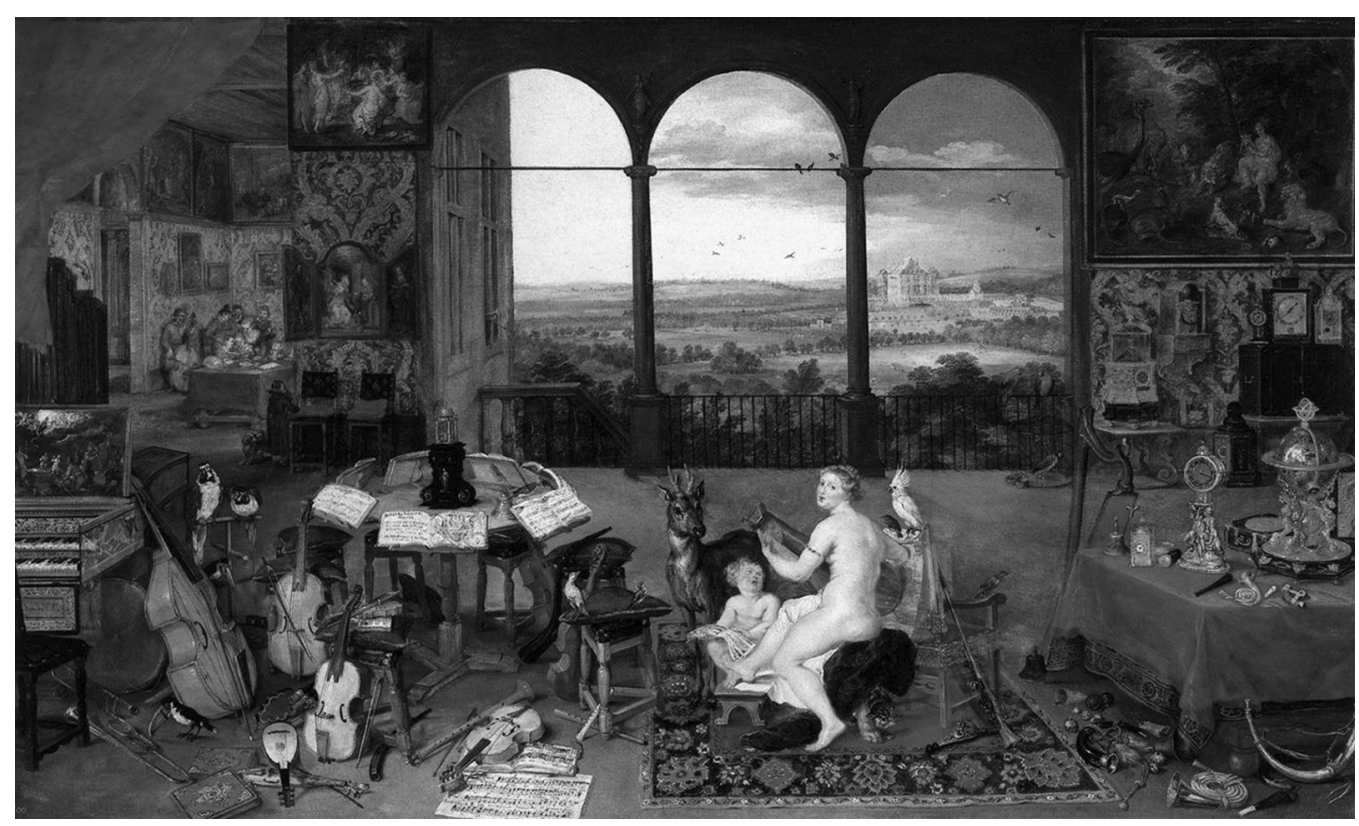

Obr. 2 Jan Brueghel starší: Alegorie sluchu (1618). Zdroj: Museo del Prado, Madrid. [cit. 2017-10-17].

Dostupné z: https://www.wga.hu/frames-e.html?/html/b/bruegel/jan_e/2/5sense1.html.

24 Srov. gestural space In SMALLEY, D. Space-Form and the Acousmatic Image. Organised Sound, 2007, 12, 1, s. 35-58. Cambridge University Press.

25 Od výstavby periodické věty až po instrumentální koncert s orchestrem.

26 Tento obraz je vskutku vynikající vizualizací mnoha aspektů prostorové poslechové zkušenosti. Stačí jen 

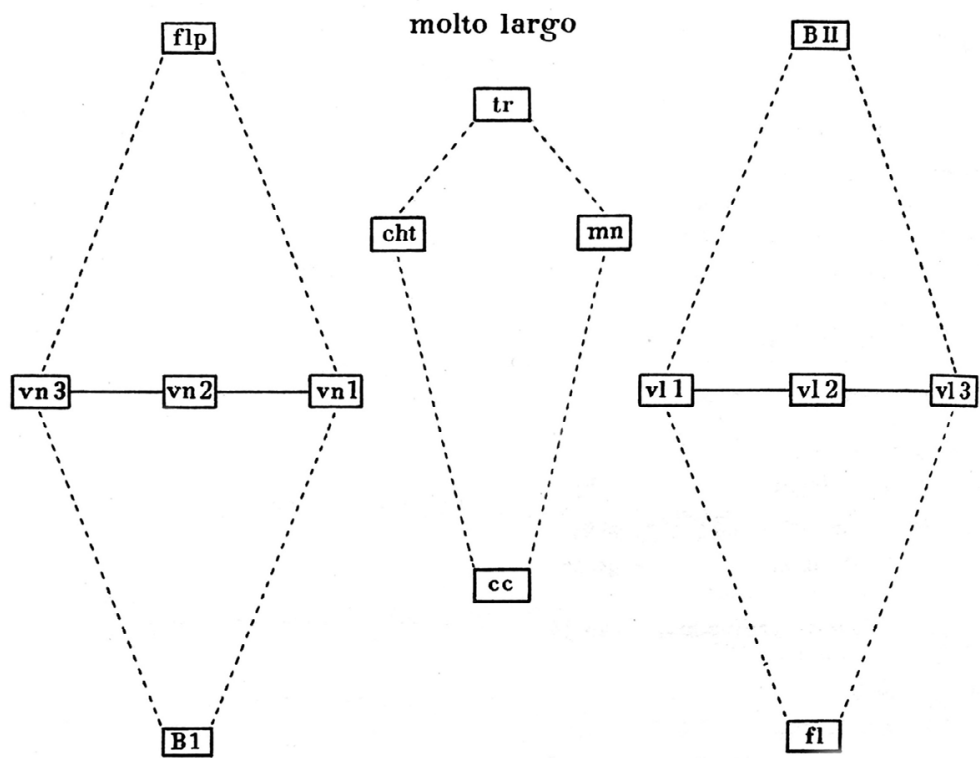

$\mathrm{D}$

Obr. 3 H. M. Górecki: Genesis (1962-63), koncept zvukových útvarů. Zdroj: Partitura díla. Kraków: Polskie wydawnictwo muzyczne, 1977.

hlavními posluchači své vlastní produkce. Ne, že by byla vyloučena přítomnost někoho, kdo nehrál, ale záměrné prostorové efekty ve skladbách vznikající, mohou být plně čitelné pouze z pozice hráče, který je jejich součástí. Je ovšem nutné dodat, že autoři skladeb pro violový consort pracují cíleně i s parametrem světlosti, ${ }^{27}$ tudíž skladby působí do určité míry prostorově i při frontálním poslechu. ${ }^{28}$

Situace v koncertním sále je od dvou výše zmíněných diametrálně odlišná. Je nutné si uvědomit, že klasické rozestavění symfonického orchestru s vlivem rozdílné vzdálenosti různých nástrojů od posluchače do určité míry počítá, když umístuje nejprůraznější nástroje povětšinou dozadu. ${ }^{29}$ Také akustika koncertních sálů bývá navržena s cílem vytvořit předpoklady pro pokud možno vyrovnaný, kompaktní zvuk. Navíc hloubka koncertních pódií (při uvážení distance od posluchače uprostřed sálu) obyčejně není taková, aby měla výrazný vliv na dojem rozdílné vzdálenosti zvukových zdrojů a umožňovala tím pádem vnímat sluchem

umístit sebe sama do různých míst prostoru, který zobrazuje a pokusit se představit si změnu zvukové krajiny, která nás obklopuje.

27 Světlost - termín zavedený Karlem Risingrem jako parametr hudební struktury, který postihuje její výškové (polohové) umístění. RISINGER, Karel. Hierarchie hudebnich celků v novodobé evropské hudbě, 1. vyd. Praha: Panton, 1969, s. 127. Srov. též pojem světlost u Carla Stumpfa. Viz SYROVÝ, Václav. Hudebni akustika, 3., dopl. vyd. V Praze: Akademie múzických umění, 2013, s. 164.

28 Viz RASTALL, R. Spatial Effects in English Instrumental Consort Music, c. 1560-1605.

29 Viz ŠPELDA, A. Akustické základy orchestrace. Srov. také historický vývoj uspořádání orchestru v souvislosti se vznikem koncertních sálů a proměnou jejich architektury. Kolb: Klangwelten für den großen Saal. In BRECH, Martha - PALAND, Ralph (eds.). Kompositionen für hörbaren Raum. 
složitěǰši prostorové vztahy. Lze tudíž jen s obtížemi počítat s umístěním nástrojů různě hluboko na koncertním pódiu jakožto formotvorným prvkem hudební struktury.

$\mathrm{V}$ tomto smyslu považuji za mylný např. koncept zvukových útvarů situovaných geometricky v prostoru před posluchačem (viz obr. 3), který použil Henryk Mikołaj Górecki ve skladbě Genesis (1962-63). ${ }^{30}$

Naopak dle mého názoru úspěšně pracuje s hloubkou frontálního prostorového umístění Toru Takemitsu ve skladbě Distance (1972) pro hoboj a šó. Autorův koncept vychází z principu ma jakožto aktivního prostoru mezi dvěma objekty. ${ }^{31}$ Hoboj stojí co nejblíže publiku, ústní bambusové varhánky šó stojí naopak od publika co nejdále. Jejich prostorový vztah je z pohledu posluchače natolik evidentní a elementární, že je snadno čitelný a vzbuzuje množství nejrůznějších asociací. Barevně jsou si oba nástroje překvapivě blízké, zvukově lze jemně proměnlivou akordickou prodlevu varhánek šó vnímat jako vzdálenou rezonanci (převážně) jednohlasého zvuku hoboje v popředí. Zajímavou paralelu s Distance pro mne představuje krajina Haboku sansui (1495), kterou namaloval japonský mistr tušového malírství Sesshū Tōyō (viz obr. 4).

Je zřejmé, že pro dojem hloubky frontálního poslechu není samotné umístění nástroje na pódiu tím nejpodstatnějším faktorem. Mnohem důležitěǰsí je pro dosažení tohoto účinku dynamika ve spojení s barvou. Vzpomeňme na dynamické „vynálezy“ skladatelů Mannheimské školy 18. stol. V této souvislosti můžeme spatřovat např. v užití dusítka, at’ už u smyčcových nebo žestových nástrojů, efekt výsostně prostorový.

Známe samožrejmě př́klady skladeb, které pro dosažení vjemu výrazné vzdálenosti požadují umístění nástrojů mimo prostory koncertního sálu. Většinou se jedná o žestové nástroje. ${ }^{32}$ Takovéto užití jiných nástrojů je poměrně vzácné. ${ }^{33}$

Umístění nástroje za pódiem (mimo pódium) je jistě velice působivý efekt, ale dnes je myslím zřejmé, že má-li vzdálenost a potažmo prostor hrát podstatnou úlohu v kompozičních strategiích skladatele, musí se stát opravdovým parametrem hudební struktury a ne jen „efektem“. Např. úvod 1. Symfonie (1887-88) Gustava Mahlera představuje do té doby netušenou hloubku perspektivy hudebního zvuku stylizující poslechovou zkušenost přírody. ${ }^{34}$ Od úvodního „ticha“ blízkých flažoletů ve smyčcích na pódiu, přes realisticky znějící volání kukačky v klarinetu, až po nesmírně vzdálené, ale zvukově ostré fanfáry trubek umístěných v zákulisí. Výraznou úlohu při vnímání perspektivní hloubky jednot-

30 Nejmarkantněji je to patrné v druhé části cyklu. HARLEY, A. M. Spatiality of sound and stream segregation in twentieth century instrumental music [online]. Organised Sound, 3, 2, 1998. s. 147-166.

31 CHENETTE, Jonathan Lee. The Concept of Ma And The Music of Takemitsu [online]. Grinnell College, Grinnell, Ia, 1985. [cit. 2017-10-17]. Dostupné z: http://adminstaff.vassar.edu/jochenette/Takemitsu_essay_Chenette.pdf.

32 V Beethovenově předehře Leonora $\check{c} .3$ můžeme nalézt trubku umístěnou za pódiem. Podobného efektu užívá i Respighi ve druhé části Pini di Roma (1924). Verdi v části Dies Irae (Tuba mirum) svého Requiem (1874) umístuje za pódiem hned 4 trubky. Podobné požadavky na žestové nástroje můžeme nalézt i u jiných skladatelů: např. R. Strauss: Ein Heldenleben (1899), Eine Alpensinfonie (1915), Die Frau ohne Schatten (1919), I. Stravinskij: Pták Ohnivák (1919), nebo B. Britten: Peter Grimes (1945).

33 Např. H. Berlioz: Symphonie Fantastique (1830) - hoboj ve 3. větě, R. Wagner: Lohengrin (1845-48) - kromě jiných i harfa, G. Verdi: Falstaff (1889-93) - kytara nebo G. Holst: Planets - Neptune (1914-16) - ženský sbor.

34 „Wie ein Naturlaut“. 


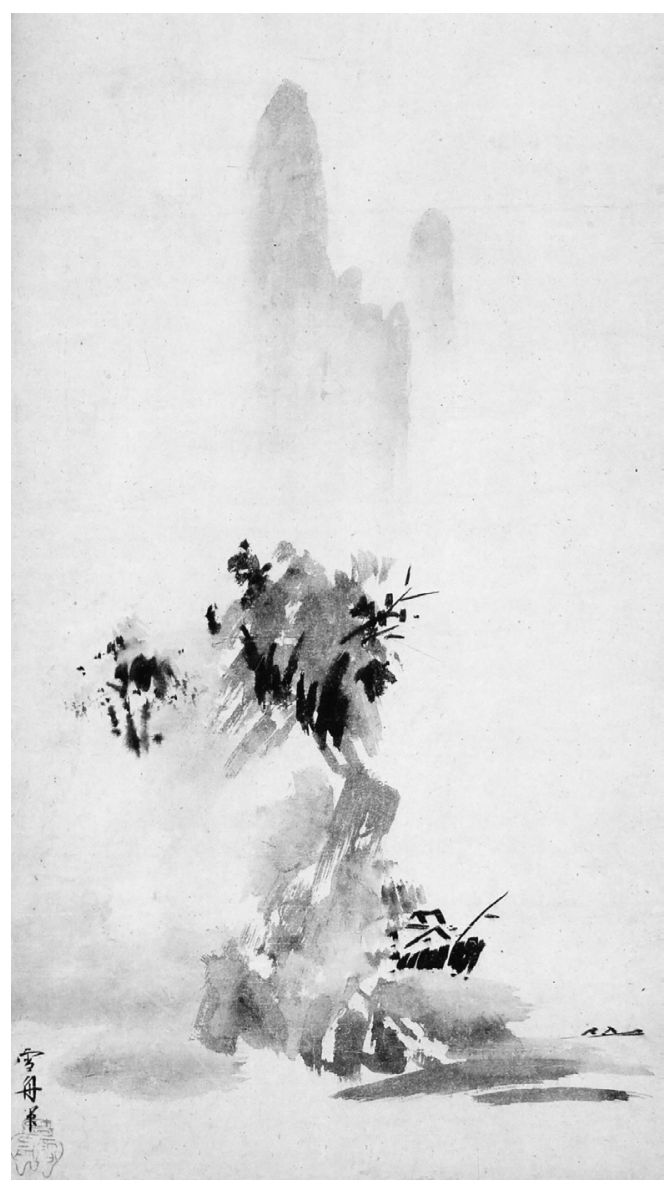

Obr. 4 Sesshū Tōyō: Haboku sansui (1495). Zdroj: [online]. Tokyo National Museum. [cit. 2017-10-18]. Dostupné z: https://www.wikiart.org/en/sesshu-toyo/haboku-sansui-1495.

livých po sobě jdoucích komponent hraje také zřetelná odlišnost subjektivního plynutí času každé z nich. Prostor se stává časem a čas se stává prostorem.

Gustav Mahler spolu s Charlesem Ivesem byli jedněmi z prvních moderních experimentátorů s fyzickým prostorem i s prostorem „uvnitř“ hudební struktury. ${ }^{35}$ Šest z Mahlerových 10 symfonií vznáší požadavky na dislokaci žestových, ale i bicích nástrojů. Pro nás je neméně zajímavé, jak Mahler pracuje s perspektivou orchestrálního zvuku mimo tyto efekty, anebo spolu s nimi. Kromě již zmíněné první symfonie může být názorným příkladem třetí věta jeho 3. Symfonie (1893-96). Jde mi o známou pasáž, ve které začíná hrát poštovní roh umístěný za pódiem. Orchestr je po vpádu šestice lesních rohů ve fortissimu

35 Pro zajímavost uvádím, že již Händel v Mesiášovi (1742) pracuje osobitým způsobem s prostorem uvnitř hudební struktury, když v č. 15 Glory to God předepisuje trubkám da lontano e un poco piano, zatímco ostatní hrají ve forte. Dociluje tak dojmu většího prostoru. Srov. také kapitolu L'Orchestre In BERLIOZ, H. Grand traité d'instrumentation et d'orchestration modernes, op. 10. 
v t. 219 postupně redukován až na prodlevu trojmo dělených prvních houslí s dusítky v nejnižší možné dynamice, kterou autor pro jistotu poté ještě dvakrát zopakuje (sempre $p p p)$. Zde nastupuje poštovní roh. Tempo je náhle zpomaleno v poměru 3:2. Housle jsou sice umístěny na pódiu, ale dojem jejich prostorového vzdálení pomocí dynamiky a změny témbru (díky rozdělení do 3 hlasů a užití dusítka), vytváří zcela jasnou souvislost se skutečně vzdáleným a vizuálně nepř́ítomným poštovním rohem. Orchestr jako by v ten moment zmizel z pódia. Předpis v partituře „Etwas zurückhaltend“ je myslím více než výmluvný.

Edgar Varése dávno před realizací Poème électronique (1958) uvažoval o „prostorovém reliéfu“ své hudby. ${ }^{36}$ Vynikajícím příkladem jsou jeho Intégrales (1924-25) pro 11 dechových nástrojů a bicí. Všimněme si, jak detailně pracuje Varése s dynamickým průběhem gest jednotlivých nástrojů či skupin - zvukových mas (sound masses) a s kontextem užití toho kterého instrumentálního témbru. V průběhu byt třeba jediného tónu nástroje mění (i několikráte a často extrémně) dynamiku. Jinými slovy subjektivně mění vzdálenost vzhledem $\mathrm{k}$ posluchači. Práce se subjektivním vnímáním prostorového umístění různých zvukových mas je v této skladbě základním formotvorným prvkem hudební struktury. Autor v této souvislosti hovoří o krystalizaci. Formu chápe jakožto výsledek procesu vývoje materiálu skladby. Forma a její obsah jsou pro něj totéž. ${ }^{37}$

\section{Přiblížení, změna měřítka poslechu (fokusace)}

Již v oddíle věnovaném hierarchizaci jsme se dotkli skutečnosti, že můžeme za určitých okolností úmyslně zaměřit své vnímání na vybrané zvukové zdroje a tak je dostat do popředí své pozornosti. Myslím, že je možno na tento proces nahlížet také obráceně jakožto na subjektivní přiblížení se ke zdroji zvuku. Z velmi malé nebo minimální vzdálenosti jsme schopni vnímat často neobyčejně subtilní zvukové detaily. Podobně jako u zrakového vjemu mikroskopem můžeme také u sluchového vjemu pomocí amplifikace ještě mnohonásobně augmentovat „měřítko“ tohoto zvětšení / přiblížení.

Jestliže jsou naše smysly po určitou dobu vystaveny částečné deprivaci (jsme např. v temném, nebo v tichém prostředí), stane se naše vnímání citlivější k jemným podnětům. Zvuky, které bychom za normálních okolností vnímali spíše na pozadí, vystupují v takové situaci do popředí naší pozornosti. Salvatore Sciarrino se ve své tvorbě zaměřuje na práci s těmi nejsubtilnějšími zvuky, jakých jsou nástroje schopny. Z jeho rozsáhlé tvorby bych rád poukázal na skladbu Introduzione all'oscuro (1981). Z hlediska hlasitosti se kompozice pohybuje někdy na samé hranici slyšitelnosti. Sciarrinovu kompoziční strategii (nejen v tomto díle) bych označil jako práci s různě artikulovaným tichem. ${ }^{38}$ Prožít absolutní

36 Viz STRAWN, J. The Intégrales of Edgard Varèse Space, Mass, Element, and Form. Perspectives of New Music, vol. 17, no. 1, 1978, s. 138-160. [cit. 2017-10-17]. Dostupné z: www.jstor.org/stable/832662.

37 VARÈSE, Edgard - CHOU WEN-CHUNG. The Liberation of Sound [online]. Perspectives of New Music, vol. 5, no. 1, 1966, s. 11-19. [cit. 2017-10-17]. Dostupné z: www.jstor.org/stable/832385.

38 „There's no such thing as silence... it is the aspect of sound that can be either expressed by sound or by its absence." KOSTELANETZ, Richard. Conversing with Cage. New York, NY: Routledge, 2003, s. 65, 51. 
„ticho“ neznamená neslyšet vůbec žádný zvuk, ale spíše díky absenci vnějších zvukových zdrojů slyšet sebe sama. At̃ už ve spirituálním či doslovném slova smyslu. ${ }^{39}$ Nejvýraznějším, myslím, že pro každého rozpoznatelným a autorem přiznaným ${ }^{40}$ prvkem skladby, je nápodoba některých zvuků lidského těla. Kromě dýchání je to především tlukot srdce transformovaný do úderů jazyka fagotisty o strojek. Zaostřením na jemné zvukové detaily nástrojových možností nás autor nutí k abnormálně citlivému naslouchání. Jinými slovy nás vede ke změně měřítka poslechu. Když na to přistoupíme, vstupujeme takříkajíc do intimity se zvukem (tichem) jeho skladby, ocitáme se uvnitř (našeho vlastního) těla.

Jonathan Harvey ve skladbě pro symfonický orchestr a elektroniku Speakings (2008) používá obdobnou kompoziční strategii, avšak v mnohem dynamičtější podobě. Materiál skladby vychází ze zvuků řeči.

„It is as if the orchestra is learning to speak, like a baby with its mother, or like first man, or like listening to a highly expressive language we don't understand. The rhythms and emotional tones of speech are formed by semantics, but even more they are formed by feelings - in that respect they approach song." ${ }^{11}$

Orchestr na mnoha místech první části dokonale resyntetizuje vznikající a rodící se hlásky, takže při poslouchání nahrávky bez partitury vlastně ani nevíme, co je elektronika a co živé nástroje. Osobně mám při poslechu dojem, jako by se obrovský symfonický aparát ocitl uvnitř prostoru dětských úst. Autor dosahuje dojmu maximálního možného přiblížení ke zvukovému zdroji. Máme pocit, že jsme uvnitř jeho zdroje.

Gerard Grisey v návaznosti na Stockhausena ${ }^{42}$ uvažuje o hudebním čase jako o objektivu s proměnlivou ohniskovou vzdáleností. Čím více je nějaká hudební struktura expandována v čase, tím více se naše pozornost zaměřuje na její mikrostrukturu - microphonic structure of sound. Naopak čím více je hudební struktura komprimována v čase, tím více se naše pozornost přesouvá na její makrostrukturu - macrophonic event. Grisey hovoří o stupnici zvukové blizkosti (proximity scale), která vychází z pravidla, jež definuje takto: "the acuity of auditory perception is inversely proportional to that of temporal perception." 43 Jak vypadá u Griseyho taková změna hloubky ostrosti, tedy subjektivní přiblížení ke zvukovému zdroji či vzdálení se od něj? Např. ve skladbě Modulations (1976-77) pro orchestr můžeme najít vhodnou pasáž pro ilustraci tohoto procesu. V čísle 37 vidíme, že orchestr je rozdělen do 4 ansámblů, každý po 5 nástrojích, které postupně vstupují se

39 Viz Cageho zkušenost v bezodrazové místnosti. In CAGE, John. Silence: Lectures and Writings. 50th Anniversary Edition. Middletown: Wesleyan univ press, 2013.

40 „Dans Introduzione all'Oscuro, l'imitation, le transfert de certains sons physiologues est évident : une sorte d'objectivation, une dramatisation muette de la pulsation cardiaque et de la respiration. " Doustupné z: http://www.salvatoresciarrino.eu/Data/Catalogo/Introduzione_all_oscuro.html\#dummy.

41 HARVEY, Jonathan. Speakings: Programme Notes [online]. 2008. [cit. 2017-10-17]. Dostupné z: http://www. fabermusic.com/repertoire/speakings-5282.

42 STOCKHAUSEN, Karlheinz. How Time Passes. In Musical Craftsmanship. Universal Edition, 1959 (1975).

43 GRISEY, Gérard. Tempus ex Machina: A composer's reflections on musical time. In Contemporary Music Review, vol. 2. Harwood Academic Publishers GmbH, 1987, s. 239-275. 
svými frázemi o 7 tónech. Tyto mají stavbu připomínající spektrální prủběh přirozeného zvukového zdroje. ${ }^{44}$ Základem je vždy nejhlubší linie. Čím vyšší linie, tím rychlejší je její průběh, čím rychlejší je její průběh, tím později začíná a dříve končí. Ačkoli je hudební struktura v partituře velmi přehledná, její průběh je natolik rychlý (časově komprimovaný), že ji vnímáme jen v obrysech jako v podstatě nahodilou heterofonii 20 samostatných hlasů. V následujícím dění dochází $\mathrm{k}$ postupnému zpomalování (časové expanzi) frází. Jeden takt před číslem 38 zjištujeme, že expanze linií je tím větší, čím jsou rychlejší, tudíž postupně dochází k rytmickému unisonu. Z 20 nahodilých hlasů se stává polyfonie 4 homofonních pásem. Naše percepce postupně začíná odhalovat jejich harmonické a barevné kvality a vztahy mezi nimi. Dostáváme se dovnitř znějícího zvuku.

\section{Závěrem}

V situaci, kdy uslyšíme za sebou své jméno, nebo zvuk, který by mohl být hrozbou se pravděpodobně otočíme tak, abychom byli čelem k jeho zdroji. Naše oči jsou posazeny (na rozdíl od mnoha zvířat) tak, že se díváme dopředu. Je tedy přirozené, že i naše komunikace s okolním probíhá nejčastěji frontálně. Oproti zraku, jehož rozlišení roste směrem k centru zorného pole je schopnost rozlišení sluchových vjemů nejvyšší v úhlu ca $120^{\circ 45}$ a to $\mathrm{v}$ rovině horizontální. $\mathrm{V}$ rovině vertikální a při umístění zvukových zdrojů za námi je naše schopnost lokalizace zvukových zdrojů mnohem menší. Umístění nástrojů na pódiu frontálně před posluchače, tak jak k němu došlo v průběhu historie, je myslím ve světle výše uvedeného logické. Vidíme hudebníky a dokážeme velmi přesně rozlišit zvukové zdroje především v panoramatu. Je ovšem pravda, a týká se to zvláště novodobých koncertních sálů s menším dozvukem, že jsme tím potlačili jeden z podstatných aspektů prostorové poslechové zkušenosti, a tím je imerzivní, do sebe vtahující schopnost zvuku, který nás obklopuje. Tento účinek bývá zpravidla ještě znásoben v případě užití elevace - vertikálního odstínění umístění zvukových zdrojů, které dává vzniknout pocitu, že jsme součástí rezonance prostoru (at̉ už skutečného či virtuálního), a že se v něm můžeme svobodně pohybovat. Přestáváme být „pozorovatelem“ zvukového dění a stáváme se jeho součástí. Přirovnal bych to k rozdílu sledování filmu v televizi a v kině vybaveném systémem Dolby Surround.

Skladatel může i při frontálním umístění nástrojů pracovat s prostorem, který je obklopuje, nebo ještě lépe s jeho iluzí. Mnozí autoři např́ič hudební historií počítali s akustickými vlastnostmi konkrétního prostoru, ${ }^{46}$ ve kterém měla být jejich skladba provede-

44 Graficky připomíná také průběh amplitudy signálu žestových nástrojů.

45 Myšleno jako výseč kruhu při pohledu vpřed. EMMERSON, Simon. Local/Field and Beyond. In BRECH, M. - PALAND, R. (eds.). Kompositionen für hörbaren Raum: Die frühe elektroakustische Musik und ihre Kontexte = Compositions for Audible Space: The Early Electroacoustic Music and its Contexts. Bielefeld: transcript Verlag, 2015, s. 15.

46 Vynikající studie Händelových kompozičních strategií ve vztahu k prostoru, pro který komponoval je In BAUMANN, Dorothea. Music and Space A Systematic and Historical Investigation into the Impact of Architectural Acoustics on Performance Practice Followed by a Study of Handel's Messiah. Bern: Peter Lang, 2011. 
na. ${ }^{47}$ Vždyt jen klasická práce s orchestrálním pedálem je typickou ukázkou tvưrčího využití dozvukovosti. Skladatel také může pracovat iluzí dislokovaných zvukových zdrojů. Takovýmto způsobem na mě působí např. první část Le désert z Messiaenovy orchestrální skladby Des canyons aux étoiles (1971-74). Autor v ní postupně exponuje oddělené, zdánlivě nesourodé zvukové objekty. Barevně jsou jednotlivé zvukové objekty (vertikální osa) velmi homogenní, mezi sebou však důsledně heterogenní (horizontální osa). Jakoby každý objekt reprezentoval odlišné zvukové prostředí, jiný prostor. Tyto a další oblasti však nechávám záměrně mimo rámec tohoto textu, nebot se jimi zabývám jinde.

V hodinách instrumentace pozoruji, že studenti často pracují se zvukem metodou „fixně rozdělených rolí“. Např. vztah mezi popředím a pozadím je pro ně mnohdy de-facto neměnný. Chápání instrumentace, jakožto práce s prostorem (at̉ už reálným či iluzivním) nám může pomoci ke kýžené změně úhlu pohledu. Ukazuje se, že lze vidět dva základní póly, archetypy při rozlišování vztahů mezi zvukovými zdroji, a tím je jejich homogenita a heterogenita. Nejedná se o dichotomii, ale spíše o plynulou škálu, postupný přechod od jednoho k druhému. Ve spojení s parametry prostorové poslechové zkušenosti nám umožňují nahlížet na principy fungování hudební struktury bez ohledu na styl, historické období nebo použité nástroje či technologie.

Stat’ vznikla jako př́pravná studie pro kapitolu kolektivni monografie $k$ problematice hudby a prostoru momentálně pripravované $k$ vydání v NAMU, Praha.

\section{Bibliography}

AUGOYARD, Jean-François - TORGUE, Henry. Sonic Experience: a Guide to Everyday Sounds. Montreal: McGill-Queens university Press, 2011.

BATES, Enda. The Composition and Performance of Spatial Music [online]. Dublin: Trinity College, 2009. [cit. 2017-10-20]. Dostupné z: http://www.endabates.net/Enda\%20Bates\%20-\%20 The\%20Composition\%20and\%20Performance\%20of\%20Spatial\%20Music.pdf.

BERANEK, Leo L. Acoustics. Woodbury NY: Acoustical Society of America, 1996.

BERLIOZ, Hector. Grand traité d'instrumentation et d'orchestration modernes, Op.10 [online]. Paris: Schonenberger, n.d., 1844. [cit. 2017-11-06]. Dostupné z: http://hz.imslp.info/files/imglnks/ usimg/8/89/IMSLP88917-PMLP28373-Traite1843ed1c.pdf.

BLOCK, Geoffrey Holden - BURKHOLDER, J. Peter. Charles Ives and the Classical Tradition. New Haven: Yale University Press, 1996.

BORIO, Gianmario - GALLIANO, Luciana (eds.). Musica che affronta il silenzio: scritti su Tōru Takemitsu = Music Facing Up to Silence. Writings on Tōru Takemitsu. Pavia: Pavia University Press, 2010.

BAUMANN, Dorothea. Music and Space A Systematic and Historical Investigation into the Impact of Architectural Acoustics on Performance Practice Followed by a Study of Handel's Messiah. Bern: Peter Lang, 2011.

BRECH, Martha - PALAND, Ralph (eds.). Kompositionen für hörbaren Raum: Die frühe elektroakustische

47 Např. Beethoven nebo Mahler prováděli instrumentační retuše svých symfonií tak, aby jejich zvuk vycházel dle jejich představ $\mathrm{v}$ tom kterém sále. 
Musik und ihre Kontexte = Compositions for Audible Space: The Early Electroacoustic Music and its Contexts. Bielefeld: transcript Verlag, 2015.

BUNCH, James Denis. A Polyphony of the Mind: Intertextuality in the Music of Salvatore Sciarrino. Urbana, Ill. : University of Illinois at Urbana-Champaign, 2016.

C. J. Darwin and R. W. Hukin. Effects of reverberation on spatial, prosodic, and vocal-tract size cues to selective attention [online]. The Journal of the Acoustical Society of America, 2000, 108, 1, s. 335-342. [cit. 2017-10-19]. Dostupné z: http://dx.doi.org/10.1121/1.429468.

CAGE, John. Silence: Lectures and Writings, 50th Anniversary Edition. Middletown: Wesleyan univ press, 2013.

Contemporary Composition Practices. [cit. 2017-10-20]. Dostupné z: http://www.okonsar.com/Documents/ligeti/ligeti.pdf.

Malham, D. C. Approaches to spatialisation [online]. Organized Sound, 3, 2, 1998, s. 167-177. Dostupné z: http://dx.doi.org/10.1017/S135577189800209X.

DEUTSCH, Diana: Psychology and Music. In BORNSTEIN, Marc H. Psychology and Its Allied Disciplines. 3, 3. Hillsdale, NJ [u.a.]: Erlbaum, 1984, s. 155-194.

EMMERSON, Simon. Aural landscape: musical space [online]. Organised Sound. 3, 2, 1998. s. 135140. [cit. 2017-10-25]. Dostupné z: https://doi.org/10.1017/S1355771898002064.

GIESELER, Walter - LOMBARDI, Luca - WEYER, Rolf-Dieter. Instrumentation in der Musik des 20. Jahrhunderts. Celle: Moeck, 1985. 331 s. ISBN 978-0-393-09740-5.

GOINES, Lisa - HAGLER, Louis. Noise Pollution: A Modern Plague [online]. Southern Medical Journal. 100, no. 3, 2007. s. 287-294. [cit. 2017-10-28]. Dostupné z: http://www.greencarintegrity.org/Noise_Pollution_A_Modern_Plague.pdf.

GRISEY, Gérard. Tempus ex Machina: A composer's reflections on musical time. Contemporary Music Review, vol. 2. Harwood Academic Publishers GmbH, 1987. s. 239-275.

HARLEY, Maria Anna. Spatiality of sound and stream segregation in twentieth century instrumental music [online]. Organised Sound, 3, 2, 1998. s. 147-166.

HARVEY, Jonathan. Speakings: Programme Notes [online]. 2008. [cit. 2017-10-17]. Dostupné z: http://www.fabermusic.com/repertoire/speakings-5282.

HONEGGER, Arthur. Jsem skladatel. 1. vyd. Bratislava Praha: Supraphon, 1967.

HOŘÍNKA, Slavomír. Barva zvuku a hierarchie v tektonice. Orchestrace jako otevrený proces: sbornik studii. 1. díl. Vyd. 1. Praha: Triga, 2009. 209 s. ISBN 978-80-904266-9-6.

CHENETTE, Jonathan Lee. The Concept of Ma And The Music of Takemitsu [online]. Grinnell College, Grinnell, Ia, 1985. [cit. 2017-10-17]. Dostupné z: http://adminstaff.vassar.edu/jochenette/Takemitsu_essay_Chenette.pdf.

CHERRY, Colin E. Some Experiments on the Recognition of Speech, with One and with Two Ears [online]. Woodbury, NY: American Institute of Physics for the Acoustical Society of America, 1953. [cit. 2017-10-19]. Dostupné z: http://dx.doi.org/10.1121/1.1907229.

KOSTELANETZ, Richard. Conversing with Cage. New York, NY: Routledge, 2003.

LACHENMANN, Helmut - HA“'USLER, Josef. Musik als existentielle Erfahrung: Schriften 19661995. Wiesbaden [u.a.]: Breitkopf \& Ha"rtel, 2004.

LEIBOVICH, Nizan. Empty Spaces: Temporal Structures and Timbral Transformations in Gérard Grisey's Modulations and Release For 12 Musicians, An Original Composition. University of Pittsburgh, 2017.

MELKA, Alois. Základy experimentálni psychoakustiky. 1. vyd. Praha: Nakladatelství Akademie múzických umění v Praze, 2005. 325 s. ISBN 80-7331-043-0.

MEYER, Jürgen. Akustik und musikalische Aufführungspraxis: leitfaden für Akustiker, Tonmeister, Musiker, Instrumentenbauer und Architekten. Frankfurt am Main: Verlag des Musikinstrument, c1972. 
Miller, James D. Effects of Noise on People [online]. Journal of the Acoustical Society of America, vol. 56, 1974, s. 729-764. [cit. 2017-10-20]. Dostupné z: http://dx.doi.org/10.1121/1.1903322.

MRKVIČKA, Luboš. Barva a souzvuk. Vyd. 1. Praha: Triga, 2008. 131 s. ISBN 978-80-904266-1-0.

PÁLKA, Tomáš. Prostor a tektonika v hudebni kompozici. Vyd. 1. Praha: Triga, 2008. 70 s. ISBN 978-80-904266-5-8.

RASTALL, Richard. Spatial Effects in English Instrumental Consort Music, c.1560-1605 [online]. Early Music, 25, 2, s. 269-288. [cit. 2017-10-17]. Dostupné z: http://www.jstor.org/stable/3128521.

RISINGER, Karel. Hierarchie hudebnich celků v novodobé evropské hudbě. 1. vyd. Praha: Panton, 1969. $228 \mathrm{~s}$.

RUSSOLO, Luigi. The Art of Noises. New York: Pendragon Pr, 1986.

RYCHLÍK, Jan a kol. Moderni instrumentace: vyšši orchestračni technika jednotlivých hudebních nástrojů. 1. vyd. Praha: Panton, 1968. 685 s.

SCIARRINO, Salvatore. Introduzione all'oscuro: Nota dell'autore [online]. 1996. [cit. 2017-10-17]. Dostupné z: http://www.salvatoresciarrino.eu/Data/Catalogo/Introduzione_all_oscuro.html\#dummy.

SCIARRINO, Salvatore. Le figure della musica: da Beethoven a oggi. Milano: Ricordi, 1998.

SCHAFER, Raymond Murray. I Have Never Seen a Sound. Canadian Acoustics - Acoustique Canadienne. 37, no. 3, 2009. s. 32-34.

SCHAFER, Raymond Murray. The Soundscape: Our Sonic Environment and the Tuning of the World. Vermont Rochester: Destiny Books, 1994. 301 s. il. ISBN 0-89281-455-1.

SMALLEY, Denis. Space-Form and the Acousmatic Image. Organised Sound, 2007, roč. 12, č. 01, s. $35-58$.

STOCKHAUSEN, Karlheinz. How Time Passes. In Musical Craftsmanship. Universal Edition, 1959 (1975).

STRAWN, John. The Intégrales of Edgard Varèse Space, Mass, Element, and Form. Perspectives of New Music, vol. 17, no. 1, 1978, s. 138-160. [cit. 2017-10-17]. Dostupné z: http://www.jstor.org/ stable/832662.

SYROVÝ, Václav. Hudebni akustika. 3., dopl. vyd. V Praze: Akademie múzických umění, 2013. 440 s. ISBN 978-80-7331-297-8.

ŠPELDA, Antonín. Akustické základy orchestrace. 1. vyd. Praha: Panton, 1967. $201 \mathrm{~s}$.

TAKEMITSU, Toru - KAKUDO, Yoshiko - GLASOW, Glenn. Confronting Silence: Selected Writings. Berkeley, Cal: Fallen Leaf Press, 1995.

THOMPSON, Emily Ann. The Soundscape of Modernity: Architectural Acoustics and the Culture of Listening in America, 1900-1933. Cambridge, Mass. [u.a.]: MIT Press, 2008.

TROJAN, Jan. Akustická ekologie a soundscape v kontextu médii. 1. vyd. Praha: Triga, 2011. 116 s. ISBN 978-80-904506-4-6.

TRUAX, Barry. Music, Soundscape and Acoustic Sustainability [online]. [cit. 2017-10-28]. Dostupné z: https:// www.sfu.ca/ ${ }^{\sim}$ truax/Sustainability.pdf.

TRUAX, Barry. Soundscape Composition As Global Music: Electroacoustic Music As Soundscape. Organised Sound. 13, no. 2, 2008. s.103-110.

VARĖSE, Edgard - Chou Wen-chung. The Liberation of Sound [online]. Perspectives of New Music, vol. 5, no. 1, 1966, pp. 11-19. [cit. 2017-10-17]. Dostupné z: http://www.jstor.org/stable/832385.

WALLIN, Nils Lennart - MERKER, Björn - BROWN, Steven (eds.). The Origins of Music. Cambridge: MIT Press, 2005. 


\section{Scores}

BEETHOVEN, Ludwig van. Ouverture No. 3 zur Oper Leonore (Fidelio), op. 72. Breitkopf \& Härtel. BERLIOZ, Hector. Symphonie fantastique [online]. New Edition of the Complete Works, Vol. 16 (pp.5-164), Kassel: Bärenreiter-Verlag, 1971. [cit. 2017-10-31]. Dostupné z: http://imslp.eu/ files/imglnks/euimg/a/aa/IMSLP108893-PMLP03653-NBE_-_Symphonie_Fantastique_-_V._ Songe_d'une_Nuit_du_Sabbat.pdf.

BRITTEN, Benjamin. Peter Grimes : an Opera in three Acts and a Prologue op. 33: Boosey \& Hawkes.

DALLAPICCOLA, Luigi. Piccola musica notturna. Zürich, ARS VIVA - Verlag Hermann Scherchen, 1954.

GÓRECKI, Henryk Mikołaj. Genesis : I. Elementi per tre archi, II. Canti strumentali per 15 esecutori, III. Monodram per soprano, metalli di percussione e sei violbassi. Kraków: Polskie wydawnictwo muzyczne, 1977.

GRISEY, Gérard. Modulations: pour 33 musiciens. San Giuliano Milanese: Ricordi, 1978.

HÄNDEL, Georg Friedrich. The Messiah: oratorio in three parts = Der Messias: Oratorium in drei Teilen . Kassel: Bärenreiter, 1996.

HARVEY, Jonathan. Speakings: for orchestra and electronics (2008). London: Faber Music, 2008.

HOLST, Gustav. The Planets : suite for large orchestra : op. 32. London: Eulenburg, 1985.

LIGETI, György. Atmospheres : für groses Orchestr. Vienna: Universal Edition, c1963. 1 partitura (19 s.). ISBN 978-3-7024-1691-1.

MAHLER, Gustav. Sechste Symphonie: für grosses Orchester [online]. Leipzig: Kahnt Universal Edition, c1906. [cit. 2017-10-29]. Dostupné z: http://hz.imslp.info/files/imglnks/usimg/5/5c/IMSLP13120-Mahler-Symphony_No.6_I.pdf.

MAHLER, Gustav. Symphonie Nr. 1 [online]. Vienna: Universal Edition, 1906. Plate U.E. 2931. [cit. 2017-10-29]. Dostupné z: http://ks.imslp.info/files/imglnks/usimg/d/dd/IMSLP17070-Mahler-Symph1fs.pdf.

MAHLER, Gustav. Symphonie Nr. 3 in sechs Sätzen für grosses Orchester, Altsolo, Knabenchor und Frauenchor. Wien: Universal Edition, c1935.

MESSIAEN, Olivier. Des canyons aux étoiles: pour piano solo, xylorimba, glockenspiel, et orchestre. Paris: Alphonse Leduc, 1978.

REICH, Steve. Music for 18 musicians : for ensemble. Milwaukee: Boosey \& Hawkes, 2000 (2015).

RESPIGHI, Ottorino. Pini di Roma: poema sinfonico [online]. Milano: Ricordi, 1925. [cit. 2017-1018]. Dostupné z: http://imslp.eu/files/imglnks/euimg/3/39/IMSLP05603-Respighi_-_Pini_ di_Roma_(full_score).pdf.

SCIARRINO, Salvatore. Introduzione all'oscuro: per 12 strumenti. Milano: Ricordi, 1981.

STRAUSS, Richard. Ein Heldenleben : Tondichtung für groses Orchester : Op. 40. Leipzig: Leuckart Universal Edition, c1899.

STRAUSS, Richard. Eine Alpensinfonie : Op. 64. Leipzig: Leuckart, c1915.

STRAVINSKIJ, Igor. Suite, tirée du conte dansé L'oiseau de feu = The firebird: (1910): pour orchestre. New York: Kalmus, [199-?]. Kalmus orchestra library; A 2132.

VARÉSE, Edgar. Intégrales: for 11 Wind Instruments and Percussion. New York: Colfranc Music Publishing, 1926 (1980).

VERDI, Giuseppe. Requiem für vier Solostimmen, Chor und Orchester : Totenmesse. Leipzig: Peters, 1958.

VERDI, Giuseppe. Falstaff. Milano: Ricordi, (c1912).

WAGNER, Richard. Lohengrin : romantische Oper in drei Akten. Leipzig: Peters, 1960. 